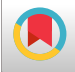

\title{
Bacteria in Carcinogenesis and Cancer Prevention: A Review Study
}

\author{
Negin Nokhandani (iD ${ }^{1}$, Arash Poursheikhani ${ }^{2}$, Mahdieh Naghavi Alhosseini ${ }^{3}$ and Homa Davoodi (iD) ${ }^{4}{ }^{*}$ \\ ${ }^{1}$ Laboratory Sciences Research Center, Golestan University of Medical Science, Golestan, Iran \\ ${ }^{2}$ Medical Genetics Research Centre, Faculty of Medicine, Mashhad University of Medical Sciences, Mashhad, Iran \\ ${ }^{3}$ Golestan University of Medical Sciences, Golestan, Iran \\ ${ }^{4}$ Cancer Research Center, Golestan University of Medical Sciences, Golestan, Iran \\ "Corresponding author: Cancer Research Center, Golestan University of Medical Sciences, Golestan, Iran. Email: homdavoodi@yahoo.com
}

Received 2020 August 09; Revised 2020 November 16; Accepted 2020 November 23.

\begin{abstract}
Context: Although conventional therapies improve the conditions of patients with cancer, adverse side effects, and resistance to different therapies have convinced scientists to use alternative methods to overcome these problems. One of the most promising research directions is the application of specific types of bacteria and their components to prevent and treat different cancers. Apart from the ability of bacteria to modulate immune responses, various particular properties such as toxin production and anaerobic lifestyle, have made them one of the potential candidates to help cancer therapy.

Evidence Acquisition: In this review, the latest information on the role of bacteria in carcinogenesis and cancer prevention in PubMed, Google scholar, and Science Direct databases in 2020 were considered using a combination of keywords "bacteria", "carcinogenesis", "cancer" and "prevention".

Results: Bacteria-cancer interactions can be studied in 2 areas of bacteria and carcinogenesis and the other bacteria and cancer treatment or prevention. In this review, bacterial carcinogenicity has been mentioned with 3 main mechanisms: bacterial toxin, bacterial metabolites, and chronic inflammation caused by bacteria. Bacterial-mediated tumor therapy (BMTT) is briefly discussed in 8 mechanisms including tumor-targeting bacterial therapy, gene therapy and vectors, bacterial products, arginine metabolism, magnetotactic bacteria, combination bacteriolytic therapy (COBALT), immunomodulation of bacteria in cancer, and immune survival.

Conclusions: The importance of bacteria in terms of diversity in their interaction with humans, as well as their components that can affect homeostasis and the immune system, has made them a powerful factor in describing the human condition in health and disease. These important elements can be used in the prevention and treatment of many complex diseases with different origins like cancer. The present study can provide an overview of the role of bacteria in cancer development or prevention and potential approaches for bacteria in cancer therapy.
\end{abstract}

Keywords: Bacteria, Carcinogenesis, Cancer

\section{Context}

Cancer is the second leading cause of death globally and was responsible for 9.6 million deaths in 2018. Approximately 1 in 8 men and 1 in 10 women suffer from cancer (1). Carcinogenesis is an evolutionary process that arises from several cellular events such as genetics aberrations, dysregulation of signaling pathways, and epigenetics which leads to clonal selection and expansion of the tumor cells (2). However, the underlying mechanisms of cancer pathogenesis remain largely unknown. Although many patients benefit from various cancer therapies such as radical surgery, radiotherapy, and chemotherapy, half of them experienced tumor regression and resistance to conventional chemotherapies (3). Therefore, there is a necessary need for developing a new strategy to overcome this phenomenon. New approaches such as photodynamic therapy, gene therapy, telomerase therapy, hyperthermia therapy, immunotherapy, complementary and alternative therapy, diet therapy, insulin potentiating therapy, and bacterial treatment have been developed for cancer treatment (4). Since bacteria, as internal and external factors, have a major role in health and human diseases they play a very effective role in the prevention and development of cancer. A large body of evidence has unraveled the dichotomous manner of bacteria in tumorigenesis. On the one hand, the development of some cancers is strongly attributed to bacterial infection and over 15\% of malignancies in the world can be linked to this agent. For instance, Helicobacter pylori infection is the main risk factor for gastric cancer development (5). Bacteria cause cancer 
by different mechanisms including the production of bacterial components, such as toxins and metabolites, as well as bacterial-induced chronic inflammation. On the other hand, some bacteria have been used for the prevention and treatment of cancers through different mechanisms including tumor-targeting bacterial therapy, gene therapy, bacterial products, arginine metabolism, magnetotactic bacteria, combination bacteriolytic therapy (COBALT), and immunomodulation of bacteria. Hereby, we reviewed the role of bacterial mechanisms in cancer development or prevention and evaluated potential approaches for bacterial cancer therapy.

\section{Evidence Acquisition}

A total of 80 articles in English and Persian language were considered in this study and the latest information on the role of bacteria in carcinogenesis and cancer prevention were obtain through searching in Google scholar databases, Science Direct, and PubMed until 2020, using a combination of the keywords "bacteria", "carcinogenesis", "cancer" and "prevention". Articles were divided into 2 groups: carcinogenic and cancer prevention, then subtitles were determined based on an overview of related articles.

\section{Results}

\subsection{Bacteria and Carcinogenesis}

It has been shown that bacterial and viralinflammatory microenvironments mediate the tumorigenesis process. Interaction between some microorganisms and immune systems results in chronic inflammation which leads to cancer establishment consequently (6). In the case of the mentioned points above, previous studies demonstrated that there is a significant relationship between $H$. pylori infection and gastric cancer. Moreover, chronic inflammation caused by Escherichia coli, Fusobacterium nucleatum, and Bacteroides fragilis has a main role in the pathogenesis of colon cancer. The bacteria can also drive cancer through their toxins, metabolites, and chronic microenvironment inflammation (7). Chronic stimulation of reactive oxygen species (ROS), interleukin-8 (IL-8), cyclooxygenase-2 (COX-2), and nitric oxide (NO) along with environmental factors are shown to significantly contribute to this process (6). Data are summarized in Table 1.

\subsubsection{Bacterial Toxins}

There are numerous bacterial toxins and antibiotics as virulence factors that eradicate and inhibit the proliferation of other microorganisms (17). Among virulence factors, bacterial protein toxins, including those connected to the development of cancer, have been the targets of a large number of studies. Bacterial toxins have great impacts on cellular and molecular procedures which are probably related to carcinogenesis such as proliferation, death, development, and differentiation of cells. Some of the prominent examples including DNA-damage toxin [colibactin, cytolethal distending toxin (CDT), cycle inhibiting factor (CIF), and cytotoxic necrotizing factor (CNF)], cell signaling disrupting toxin [cytotoxin-associated gene-A (CagA), vacuolating cytotoxin $\mathrm{A}(\mathrm{VacA})$, B. fragilis toxin, and avirulence protein $A$ and Fad] (Table 2).

It has been demonstrated that some E. coli strains produce peptide-type genotoxin colibactin which have a meaningful contribution to cancer development by double-strand DNA breakage $(18,19)$. Overpresenting of $E$. coli harboring the colibatin-producing genes was recently illustrated that in the colorectal tumors samples (20). In one more example, it has been indicated that cdtB, a cytolethal distending toxin subunit of Salmonella enterica serovar Typhi can derive varieties of actions such as cell cycle arrest, inhibit immune cells, and chronic inflammation which has been previously elaborated in gallbladder cancer development and progression (21).

DNA-damage toxins act through destructive DNA and cause double-stranded DNA breaks. To date, digestive bacteria have this function and their toxins have contributed to cancer progression (22).

Moreover, bacterial toxins can modulate cellular procedures by alterations in signaling pathways. The cag pathogenicity island (CagA) and vacuolating cytotoxin (VacA) of H. pylori have an impact on proliferation and programmed cell death through regulating mitogenactivated-protein kinase (MAPK) and epidermal growth factor receptor (EGFR) pathways (26).

\subsubsection{Bacterial Metabolites}

Bacterial metabolites such as nitrosamines, bile acid degradation products, and acetaldehyde can be associated with different cancers. Previous studies revealed that the production of toxic metabolites was influenced by a high protein and low carbohydrate diet. This diet decreases the production of anti-cancer metabolites and therefore increases the risk of tumorigenesis. These oncogenic metabolites can cause tumors through mutations in DNA and increase the production of oxygen free radicals (27). Some important bacterial metabolites are mentioned below. 


\begin{tabular}{|c|c|c|}
\hline Cancers & Bacteria & Refrences \\
\hline Lung cancer & $\begin{array}{l}\text { Chlamydia pneumoniae; Staphylococcus aureus; Streptococcus; Escherichia } \\
\text { coli; Haemophilus influenzae; Candida albicans; Legionella pneymophila; } \\
\text { Bacillus; Listeria; Mycobacterium tuberculosis. }\end{array}$ & (8) \\
\hline Pancreatic cancer & Helicobacter pylori; Porphyromonas gingivalis. & (9) \\
\hline Ovarian cancer & Chlamydia trachomatis; Mycoplasma genitalium. & (11) \\
\hline Gallbladder carcinoma & $\begin{array}{l}\text { Salmonella enterica; Helicobacter hepaticus; Helicobacter bilis; Escherichia } \\
\text { colityphi. }\end{array}$ & $(12)$ \\
\hline $\begin{array}{l}\text { Gastric cancer mucosa-associated lymphoid tissue lymphoma } \\
\text { (MALToma) }\end{array}$ & Helicobacter pylori & $(13)$ \\
\hline Colon cancer & $\begin{array}{l}\text { Streptococcus bovis; Fusobacterium nucleatum; Citrobacter rodentium; } \\
\text { Escherichia coli; Bacteroides fragilis. }\end{array}$ & $(13)$ \\
\hline Cervical cancer & Chlamydia trachomatis & $(14)$ \\
\hline Hepatocellular carcinoma & Helicobacter hepaticus & $(14)$ \\
\hline Vascular tumor & Bartonella & $(15)$ \\
\hline Liver cancer & Helicobacter hepaticus & $(15)$ \\
\hline Prostate Cancer & Neisseria gonorrhoeae & (16) \\
\hline
\end{tabular}

Abbreviation: MALToma, mucosa-associated lymphoid tissue lymphoma.

\begin{tabular}{|c|c|c|}
\hline Strategy & Examples & Reference \\
\hline Toxicity (toxins) & DNA- damage toxin: Colibactin, CDT, Cif, CNF; Cell signaling disrupting toxin: CagA, VacA; B. fragilis toxin; Avirulence protein A; FadA. & $(23,24)$ \\
\hline Metabolites & Nitrosamines; Bile acid degradations; Acetaldehyde & $(24)$ \\
\hline Inflammation & Cytokines /ROS/RNOS & $(25)$ \\
\hline
\end{tabular}

Abbreviations: CDT, cytolethal distending toxin; Cif, cycle inhibiting factor; CNF, cytotoxic necrotizing factor; CagA, cytotoxin-associated gene-A; VacA, vacuolating cytotoxin A; FadA, fusobacterium adhesin A; ROS, reactive oxygen species; RNOS, reactive nitrogen oxide species.

\subsubsection{Nitrosamines}

In some bacteria, nitrates are converted to nitrites and $\mathrm{N}$-nitrosamines by reductase enzymes. $\mathrm{N}$-nitrosamines are mainly accounted as a remarkable mutagen (28). It has been shown that bacterial N-nitrosamines compounds are associated with bladder cancer in animal models. Furthermore, patients with chronic urinary tract infections showed a higher level of nitrosamines in comparison to controls (29).

It has been demonstrated that dimethyl nitrosamine, a powerful carcinogen, was significantly excreted in the urine in Proteus mirabilis and E. coli infection and associated with bladder cancer (30).

Interestingly, $H$. pylori hypochlorhydria has been postulated to provide a proper condition for other bacteria to produce nitrosamines. Nitrosamines produced by bacteria and rising nitrite levels might enhance the susceptibility of chronic atrophic gastritis, gastric, and colon cancer (24).

\subsubsection{Bile Acid Degradation Products}

Gastrointestinal and biliary tract bacteria can degrade bile acids to secondary products (31). Deoxycholate and lithocholate are the main parts of bile acid degradation products which cause mutation in the cells (32). Secondary bile acid products also elevate the levels of ROS by converting arachidonic acid into prostaglandins through host cell membrane enzymes and mitochondria damages. Additionally, bile acids increase nitrogen species through the induction of nitric oxide synthases. ROS and RNOS can increase DNA breakage and mutagenesis (33). It is important to know that these secondary bile acid products alone do not have the potential for carcinogenesis and need cocarcinogens like nitrosamine (34).

It has been illustrated that mixed bacterial and Salmonella infections are associated with gallbladder cancer which is mainly attributed to bacterial degradation of bile and chronic inflammation that make a mutation in oncogenes such as P53 and K-ras (12). Deoxycholate 
has been shown that promote growth and proliferation of colon cancer cells by inhibiting protein kinase $\mathrm{C}$ in the cells (35). It has been shown that a high-fat diet can stimulate the secretion of bile acids which can increase secondary bile acid products (36).

\subsubsection{Acetaldehyde}

Acetaldehyde is a mutagenic, toxic, and carcinogenic metabolite that is produced by the oxidation of ethanol from bacteria that live in the digestive tract. It interferes with DNA repair and influences tumor development (37).

It has been shown that acetaldehyde production, particularly by non-pathogenic Neisseria in oral microflora, can contribute to oral cavity carcinoma (38).

Acetaldehyde also causes breakage in chromosome and sister-chromatid exchanges leading to mutations in human lymphocytes. Previous studies showed that the production of acetaldehyde following chronic ethanol consumption increases esophageal epithelial cell generation and chances of tumor development. Furthermore, acetaldehyde causes hyperplastic and hyper-proliferative changes in the gastrointestinal tract that increase the risk of cancer (39).

\subsubsection{Chronic Inflammation}

Chronic inflammation is one of the most crucial cancer hallmarks which was explained for the first time by Virchow in 1863. He suggested the inflammatory reactions in schistosome-related bladder cancers stimulate cell proliferation and growth (40). Previous studies demonstrated that viruses and bacterial inflammation have been associated with higher cancer risks (41). Inflammation can drive the initiation and progression of cancer and it has been estimated that approximately one-sixth of human cancers occur as a consequence of pathogen inflammation (25). Inflammation stimulates cell renovation and proliferation and might result in DNA aberration that initiates and promotes carcinogenesis (40).

\subsection{Bacterial-Mediated Tumor Therapy}

For almost a century, it has been shown that bacteria can be used as a novel cancer therapy (42). However, bacteria mediated tumor therapy (BMTT) as a potential therapy with a broad range of benefits, has some limitations such as biosafety, toxicity, genetic instability, and complications with other therapies (43). It has been shown that tumor-detecting bacteria can act as a biosensor for detecting tumors, metastasis, and monitoring of residual diseases (44). Previous evidence showed that some bacteria can regress tumor cell growth by different mechanisms
(8). The first observation was tumor regression in exposure to clostridial by Vautier in 1813 (45). Then the German physicians, W. Busch and F. Fehleisen in 1868 and 1882 , individually observed that when the patients with cancer were infected with streptococcal bacteria and contracted erysipelas, their tumor was regressed (46). After that, William B. Coley in 1891 showed tumor regression in patients with sarcoma exposed to Coley's toxin (heat-killed streptococcal organisms combined with heat-killed Serratia marcescens) (47). In the early 20th century (1935), Connell showed that the tumor was regressed when treated by filtrated Clostridium histolyticum which was attributed to the production of enzymes (48). In addition, in 1976, it was shown that MycobacteriumBovis bacillus Calmette-Guérin (BCG) was administrated for bladder cancer and BCG eradicated the tumor and inhibited the probability of relapse. It is noteworthy to mention, controlled administration of bacteria is important for a successful BMTT particularly via the heat-inactivated bacteria (49). Currently, new bacterial strains with high capability are being designed and altered by genetic engineering to reduce the side effects and increase efficiency (50). For instance, the BCG vaccine can be used for human bladder cancer as adjuvant therapy (51). Moreover, oral administration of $E$. coli can provide a noninvasive detection method for finding liver metastasis via producing easily detectable color signals in urine (52).

\subsubsection{Tumor Targeting Bacterial Therapy}

Some anaerobic bacteria were investigated for targeting therapy due to their ability to live in oxygen-free regions. When bacteria are injected into tumor cells, they migrate and penetrate deeply and assemble in necrotic areas of tumor tissue and destroy it directly (53). Some strains of bacteria such as Clostridia, Bifidobacteria, Mycobacterium, Bacillus, Listeria, and Salmonellae can colonize into the hypoxic areas of tumor cells and can devastate tumor status (54). There are several methods that bacteria would help to have anti-cancer efficiency including gene therapy, bacterial products, arginine metabolites, magnetotactic bacteria, COBALT, and immunomodulation of bacteria in cancer.

\subsubsection{Gene Therapy and Vectors}

The best therapy for cancer is the precise eradication of the tumor cells with minimal damage to the other parts of the body. One of these effective therapies is gene therapy. Gene therapy is the gene manipulation and regulation of DNA to prevent and treat the disease. Gene delivery system consists of 2 biological (bacteria and viruses) and non-biological categories (55). The inherent characteristics of the bacteria allow them to have adequate and effective DNA delivery to cells or tissues. Following tumor 
progression, the cancerous cells create new blood vessels that are highly unorganized and leaky. As a result, circulating bacteria enter the tumor and accumulate through it (56). The bacteria begin to produce compounds that kill tumor cells. Additionally, bacteria can transfer some substances coupled with antitumor agents to the human body and destroy the cancerous cells (57). Previous studies have demonstrated that the bacteria that are conjugated with anti-cancer agents are more therapeutic than monotherapy (58).

Last investigations showed that co-delivery of doxorubicin and recombinant plasmid pHSP70-Plk1-shRNA by bacterial magnetosomes can significantly inhibit osteosarcoma cells (59). Previous studies indicated the overexpression of laudin-3 (CLDN3) and claudin-4 (CLDN4) in ovarian cancer. Recently it has been shown that CLDN3/4 can be targeted by recombinant Clostridium perfringens enterotoxin (CPE) fused to tumor necrosis factor as a potential therapy in ovarian cancer (60). Furthermore, it has been demonstrated that by a recombinant $E$. coli expressing listeriolysin O (LLO), antigens can effectively present to dendritic cells (DCs) for cancer immunotherapy in melanoma cells (61).

The aim of gene therapy is to incorporate genes that have anti-cancer properties to anaerobic bacteria (43).

\subsubsection{Bacterial Products in the Treatment of Cancer}

There are several natural or synthetic modified bacterial products that have been shown to have an anticancer activity such as myxobacterium Sorangium cellulosum epothilone A and epothilone B (EpoA and EpoB), EpoB, and desoxyepothilone $B$ in a wide range of cancers (62). Some bacterial components such as enzymes can act as anti-tumor agents. Previous investigations discovered the anti-tumor activity of some secreted substances of bacteria for different cancer cells. For instance, bacteriocins are positively-charged peptides that are produced ribosomally in a variety of bacteria (63). Moreover, bacterial products such as lipopolysaccharide (LPS) vaccines might act as an anti-tumor agent in particular cancers (64). For instance, LPS vaccines of Pseudomonas aeruginosa increased tumor regression and improved overall survival rate in patients with acute myeloid leukemia in comparison to nontreated LPS patients (65). A large body of evidence has revealed that LPS remarkably elevated apoptosis in colorectal cancer cell lines compared to 5-fluorouracil (5-FU) (64, 66). Moreover, staphylococcal superantigens-like(SSL) which is produced by $S$. aureus binds to overexpressed receptors in cancer cells. For example, SSL10 binds to CXCR4 on human cervical carcinoma cells and competes with CXCL12 (the natural ligand of CXCR4) and therefore, inhibits the chemotactic response of HeLa cell, calcium mobilization, and cell migration of cervical carcinoma that acts as an anti-cancer agent preventing metastasis (67). Endotoxin of Serratia marcescens increases tumor regression through its hemorrhage-producing factor (68). Of note, bacteriocins preferentially bind to the negatively-charged cell membrane of cancer cells and induce its cytotoxicity. Indeed, the cancer cell membrane has higher microvilli and fluidity in comparison to normal cells which means more number binding sites for bacteriocins. Bacteriocins conduct their cytotoxicity through induction of apoptosis and/or changing the cell membrane permeability by depolarization of it (50).

\subsubsection{Arginine Metabolism in Bacterial Pathogenesis and Can- cer Therapy}

Amino acid metabolism pathways are critical for both bacterial and cancer cell growth, and recently they have been considered as therapeutic targets for bacterial infections and cancer therapy (69). Effective cancer therapy is the depletion of key amino acids that are essential for tumors to survive (70). One of these amino acids is arginine. Correlation between arginine metabolism and tumorigenesis has been known for a long time and shows that arginine can influence tumor cell growth and proliferation (71). A huge body of studies has revealed that arginine deprivation could be a potential therapeutic approach in cancer therapy. Three major enzymes [arginase, arginine deiminase (ADI), and arginine decarboxylase (ADC)] participate in the depletion of arginine in archaea, bacteria, and eukarya (72). Studies demonstrated that, among the arginine degrading enzymes, arginine deiminase (ADI) has an antitumor effect in a variety of cancers such as hepatocellular carcinomas and melanomas (HCCs) (73). In this case, some microorganisms such as Pseudomonas, Mycoplasma, Halobacterium, Lactobacillus, Lactococcus, and Streptococcus can catabolize arginine to citrulline and ammonia by ADI enzyme (74). Of importance, Mycoplasma arginine deiminase enzyme is known as a potent anti-cancer agent that inhibits tumor growth in hepatocellular carcinoma, leukemia, melanoma, renal cell carcinoma, and prostate cancer (75).

\subsubsection{Magnetotactic Bacteria for Cancer Therapy}

Recently, nanotechnology has opened many therapeutic windows in cancer treatment. Among different new methods in this field, using magnetotactic bacteria (MTB) is one of the significant methods. MTB is a group of Gramnegative, motile, and aquatic bacteria that can move along geomagnetic field lines. These bacteria synthesized intracellular structures and nano-sized magnetic crystals, named "magnetosomes" (76). Both MTB and their magnetosomes are being applied in cancer treatment in dif- 
ferent ways. The whole MTB and magnetosomes are being used for delivering medication. Magnetococcus marinus strain MC-1 is also used to transport drugs with nanocarriers (nanoliposime) on the oxygen-free region of colorectal cancer in mice. Furthermore, scientists demonstrated the anti-tumoral activities of the complex of magnetosome and a chemotherapy medication called doxorubicin (DOX) in the cell lines of mouse breast cancer and human leukemia (77). Another interesting feature of magnetosome is the detection of tumor cells by magnetic resonance imaging (MRI). For instance, Xiang Z et al. detected breast cancer cells by magnetosome nanoparticles. The advantage of this system is that a low dosage of magnetosome can be used due to its high affinity to target cells because of specific proteins binding to the magnetosome surface (78). Another application of magnetic particles in the treatment of cancer is hyperthermia (increasing the temperature within the tumor in the range of $37-45^{\circ} \mathrm{C}$ ) which is induced by altering the magnetic field (79). Scientists demonstrated that using magnetosomes in the hyperthermia treatment of tumors reduce the size of tumor cells and eliminate the cancerous cell completely.

\subsubsection{Combination Bacteriolytic Therapy}

Different bacteria are tested for combination therapy of cancers. Among 26 various bacteria, an anaerobic bacteria named "Clostridium novyi-NT" (C. novyi without $\alpha$ toxin) which grows in the hypoxic region of the tumors seems particularly useful in cancer therapy (80). The spores of this bacteria are used in combination with several chemotherapeutic agents, such as docetaxel, vinorelbine, mitomycin C, and dolastatin-10. This strategy is called COBALT, it causes hemorrhagic necrosis of tumors which destroys tumor cells and prolongs antitumor effects (81).

\subsubsection{Immunomodulation of Bacteria in Cancer}

Immunomodulation as a part of immunotherapy includes the interaction of bacteria with the host's immune system in different ways. Bacteria can enhance human immunity through activation of inflammasome pathways and producing inflammatory cytokines, which suppress tumor growth (82). Some anaerobic bacteria initiate the defense mechanism of the host by producing anti-tumor effectors T cell (CD4, CD25, and CD8) responses (83). Some gram-positive anaerobic bacteria can augment the induction of tumor-specific $\mathrm{T}$ cells and enhance the accumulation of antigen-specific CD8 + T cells and thus destroy cancer cells (84).

\subsubsection{Immune-Surveillance}

One of the functions of the immune system is the identification and destruction of deformed and abnormal cells before they become a tumor cell, and also the removal of it after formation (85). These functions lead to the emergence of the "cancer immune-surveillance" hypothesis by Burnet and Thomas (86). Many factors are involved in immune-surveillance such as cytokines and chemokines. Tumor necrosis factor (TNF) is an inflammatory cytokine that induces hemorrhage necrosis in cancers. This cytokine has a dual role in tumor progression. On the one hand, TNF- $\alpha$ can inhibit tumor progression, on the other hand, it promotes tumor growth (87). Some bacteria were positively correlated with TNF response, while other bacteria reduced the TNF response. Engineered bacteriainduced TNF- $\alpha$ production and improved cancer treatment (88). Additionally, immune responses against liver cancer were modulated by the gut microbiome through bile acid-regulated NKT cells [natural killer (NK) cells are the main innate lymphocyte subsets that mediate antitumor and anti-viral responses (89)]. These gut bacteria use bile acid as transportation and regulate the chemokine CXCL16 level on liver sinusoidal endothelial cells (LSEC). This regulation controls the accumulation of CXCR6+ hepatic NKT cells to inhibit the development of liver tumors (90).

\section{Conclusions}

In sum, bacteria and cancer are linked to each other by different mechanisms. Bacteria are one of the most important factors contributing to the progression of cancer, whereas they are also widely used in the treatment of cancer. Since bacteria are an integral part of human life, and especially the immune system of each individual is strongly affected by the bacteria in the living environment and the bacteria within the body, so extensive research into the role of bacteria in human health and disease, especially complex diseases such as cancer, should be undertaken because there are still many questions that need to be answered.

\section{Footnotes}

Authors' Contribution: The authors contributed to all parts of writing.

Conflict of Interests: The authors declared no conflict of interest.

Funding/Support: No finding

\section{References}

1. Ferlay J, Ervik M, Lam F, Colombet M, Mery L, Piñeros M, et al. Global cancer observatory: Cancer today. Lyon, France: International Agency 
for Research on Cancer; 2020. Available from: https://gco.iarc.fr/ today.

2. Merlo LM, Pepper JW, Reid BJ, Maley CC. Cancer as an evolutionary and ecological process. Nat Rev Cancer. 2006;6(12):924-35. doi: 10.1038/nrc2013. [PubMed: 17109012].

3. Raguz S, Yague E. Resistance to chemotherapy: New treatments and novel insights into an old problem. Br J Cancer. 2008;99(3):387-91. doi: 10.1038/sj.bjc.6604510. [PubMed: 18665178]. [PubMed Central: PMC2527800].

4. Jain RK. Delivery of molecular and cellular medicine to solid tumors. Adv Drug Deliv Rev. 2001;46(1-3):149-68. doi: 10.1016/s0169409x(00)00131-9. [PubMed: 11259838].

5. Pisani P, Parkin DM, Munoz N, Ferlay J. Cancer and infection: Estimates of the attributable fraction in 1990. Cancer Epidemiol Biomarkers Prev. 1997;6(6):387-400. [PubMed: 9184771].

6. Mager DL. Bacteria and cancer: Cause, coincidence or cure? A review.J Transl Med.2006;4:14. doi:10.1186/1479-5876-4-14. [PubMed:16566840]. [PubMed Central: PMC1479838].

7. Sears CL, Garrett WS. Microbes, microbiota, and colon cancer. Cell Host Microbe. 2014;15(3):317-28. doi: 10.1016/j.chom.2014.02.007. [PubMed: 24629338]. [PubMed Central: PMC4003880].

8. Littman AJ, White E, Jackson LA, Thornquist MD, Gaydos CA, Goodman GE, et al. Chlamydia pneumoniae infection and risk of lung cancer. Cancer Epidemiol Biomarkers Prev. 2004;13(10):1624-30. [PubMed: 15466979].

9. Raderer M, Wrba F, Kornek G, Maca T, Koller DY, Weinlaender G, et al. Association between Helicobacter pylori infection and pancreatic cancer. Oncology. 1998;55(1):16-9. doi: 10.1159/000011830. [PubMed: 9428370].

10. Urbaniak C, Cummins J, Brackstone M, Macklaim JM, Gloor GB, Baban CK, et al. Microbiota of human breast tissue. Appl Environ Microbiol. 2014;80(10):3007-14. doi: 10.1128/AEM.00242-14. [PubMed: 24610844]. [PubMed Central: PMC4018903].

11. Idahl A, Lundin E, Jurstrand M, Kumlin U, Elgh F, Ohlson N, et al. Chlamydia trachomatis and Mycoplasma genitalium plasma antibodies in relation to epithelial ovarian tumors. Infect Dis Obstet Gynecol. 2011;2011:824627. doi: 10.1155/2011/824627. [PubMed: 21811380]. [PubMed Central: PMC3147007].

12. Kumar S, Kumar S, Kumar S. Infection as a risk factor for gallbladder cancer. J Surg Oncol. 2006;93(8):633-9. doi: 10.1002/jso.20530. [PubMed: 16724347].

13. Crowe SE. Helicobacter infection, chronic inflammation, and the development of malignancy. Curr Opin Gastroenterol. 2005;21(1):32-8. [PubMed: 15687882].

14. Bulhak-Koziol V, Zdrodowska-Stefanow B, Ostaszewska-Puchalska I, Mackowiak-Matejczyk B, Pietrewicz TM, Wilkowska-Trojniel M. Prevalence of Chlamydia trachomatis infection in women with cervical lesions. Adv Med Sci. 2007;52:179-81. [PubMed: 18217414].

15. Fox JG, Feng Y, Theve EJ, Raczynski AR, Fiala JL, Doernte AL, et al. Gut microbes define liver cancer risk in mice exposed to chemical and viral transgenic hepatocarcinogens. Gut. 2010;59(1):88-97. doi: 10.1136/gut.2009.183749. [PubMed: 19850960]. [PubMed Central: PMC3891362].

16. Sutcliffe S, Giovannucci E, De Marzo AM, Leitzmann MF, Willett WC, Platz EA. Gonorrhea, syphilis, clinical prostatitis, and the risk of prostate cancer. Cancer Epidemiol Biomarkers Prev. 2006;15(11):2160-6. doi:10.1158/1055-9965.EPI-05-0913. [PubMed: 17119041].

17. Becattini S, Taur Y, Pamer EG. Antibiotic-induced changes in the intestinal microbiota and disease. Trends Mol Med. 2016;22(6):45878. doi: 10.1016/j.molmed.2016.04.003. [PubMed: 27178527]. [PubMed Central: PMC4885777].

18. Arthur JC, Perez-Chanona E, Muhlbauer M, Tomkovich S, Uronis JM, Fan TJ, et al. Intestinal inflammation targets cancer-inducing activity of the microbiota. Science. 2012;338(6103):120-3. doi: 10.1126/science.1224820. [PubMed: 22903521]. [PubMed Central: PMC3645302].

19. Putze J, Hennequin C, Nougayrede JP, Zhang W, Homburg S, Karch H, et al. Genetic structure and distribution of the colibactin genomic island among members of the family Enterobacteriaceae. Infect Immun. 2009;77(11):4696-703. doi: 10.1128/IAI.00522-09. [PubMed: 19720753]. [PubMed Central: PMC2772509].

20. Cougnoux A, Dalmasso G, Martinez R, Buc E, Delmas J, Gibold L, et al. 754 tumorigenesis promoted by colibactin-producing Escherichia coli explained by the dark side of cellular senescence. Gastroenterology. 2013;144(5):S-137. doi:10.1016/s0016-5085(13)60494-1.

21. Mezal EH, Bae D, Khan AA. Detection and functionality of the CdtB, PltA, and PltB from Salmonella enterica serovar Javiana. Pathog Dis. 2014;72(2):95-103. doi: 10.1111/2049-632X.12191. [PubMed: 24891290].

22. Elliott TR, Hudspith BN, Wu G, Cooley M, Parkes G, Quinones B, et al. Quantification and characterization of mucosa-associated and intracellular Escherichia coli in inflammatory bowel disease. Inflamm Bowel Dis. 2013;19(11):2326-38. doi: 10.1097/MIB.0b013e3182a38a92. [PubMed: 23989750].

23. Dalmasso G, Cougnoux A, Delmas J, Darfeuille-Michaud A, Bonnet R. The bacterial genotoxin colibactin promotes colon tumor growth by modifying the tumor microenvironment. Gut Microbes. 2014;5(5):67580. doi: 10.4161/19490976.2014.969989. [PubMed: 25483338]. [PubMed Central: PMC4615906].

24. Carboni M, Guadagni S, Pistoia MA, Amicucci G, Lolli D, Palumbo $\mathrm{G}$, et al. Chronic atrophic gastritis and risk of N-nitroso compounds carcinogenesis. Langenbecks Arch Chir. 1988;373(2):82-90. doi: 10.1007/BF01262769. [PubMed: 3287075].

25. de Martel C, Ferlay J, Franceschi S, Vignat J, Bray F, Forman D, et al. Global burden of cancers attributable to infections in 2008: A review and synthetic analysis. Lancet Oncol. 2012;13(6):607-15. doi: 10.1016/S1470-2045(12)70137-7. [PubMed: 22575588].

26. Cover TL, Blanke SR. Helicobacter pylori VacA, a paradigm for toxin multifunctionality. Nat Rev Microbiol. 2005;3(4):320-32. doi: 10.1038/nrmicro1095. [PubMed: 15759043].

27. Russell WR, Gratz SW, Duncan SH, Holtrop G, Ince J, Scobbie L, et al. High-protein, reduced-carbohydrate weight-loss diets promote metabolite profiles likely to be detrimental to colonic health. Am J Clin Nutr. 2011;93(5):1062-72. doi: 10.3945/ajcn.110.002188. [PubMed: 21389180].

28. Ziebarth D, Spiegelhalder B, Bartsch H. N-nitrosation of medicinal drugs catalysed by bacteria from human saliva and gastro-intestinal tract, including Helicobacter pylori. Carcinogenesis. 1997;18(2):383-9. doi: 10.1093/carcin/18.2.383. [PubMed: 9054633].

29. Burin GJ, Gibb HJ, Hill RN. Human bladder cancer: Evidence for a potential irritation-induced mechanism. Food Chem Toxicol. 1995;33(9):785-95. doi: 10.1016/0278-6915(95)00045-4. [PubMed: 7557751].

30. Radomski JL, Greenwald D, Hearn WL, Block NL, Woods FM. Nitrosamine formation in bladder infections and its role in the etiology of bladder cancer. J Urol. 1978;120(1):48-50. doi: 10.1016/s00225347(17)57035-4. [PubMed: 671604].

31. Ridlon JM, Kang DJ, Hylemon PB. Bile salt biotransformations by human intestinal bacteria. J Lipid Res. 2006;47(2):241-59. doi: 10.1194/jlr.R500013-JLR200. [PubMed:16299351].

32. Hirano S, Nakama R, Tamaki $\mathrm{M}$, Masuda $\mathrm{N}$, Oda $\mathrm{H}$. Isolation and characterization of thirteen intestinal microorganisms capable of 7 alpha-dehydroxylating bile acids. Appl Environ Microbiol. 1981;41(3):737-45. doi: 10.1128/AEM.41.3.737-745.1981. [PubMed: 7224633]. [PubMed Central: PMC243769].

33. Bernstein H, Bernstein C, Payne CM, Dvorak K. Bile acids as endogenous etiologic agents in gastrointestinal cancer. World J Gastroenterol. 2009;15(27):3329-40. doi: 10.3748/wjg.15.3329. [PubMed: 19610133]. [PubMed Central: PMC2712893].

34. Narisawa T, Magadia NE, Weisburger JH, Wynder EL. Promoting effect of bile acids on colon carcinogenesis after intrarectal instillation of N-methyl-N'-nitro-N-nitrosoguanidine in rats. J Natl Cancer Inst. 1974;53(4):1093-7. doi: 10.1093/jnci/53.4.1093. [PubMed: 4427390]. 
35. Milovic V, Teller IC, Faust D, Caspary WF, Stein J. Effects of deoxycholate on human colon cancer cells: Apoptosis or proliferation. Eur J Clin Invest. 2002;32(1):29-34. doi: 10.1046/j.0014-2972.2001.00938.x. [PubMed: 11851724].

36. Nagengast FM, Grubben MJ, van Munster IP. Role of bile acids in colorectal carcinogenesis. Eur J Cancer. 1995;31A(7-8):1067-70. doi: 10.1016/0959-8049(95)00216-6. [PubMed: 7576993].

37. Cho CH, Purohit V. Interaction of Alcohol and Tobacco in Upper Aerodigestive Tract and Stomach Cancer. In: Salaspuro M, Salaspuro V, Seitz HK, editors. Alcohol, Tobacco and Cancer. Switzerland: Karger Medical and Scientific Publishers; 2006. 312 p.

38. Muto M, Hitomi Y, Ohtsu A, Shimada H, Kashiwase Y, Sasaki H, et al. Acetaldehyde production by non-pathogenic Neisseria in human oral microflora: implications for carcinogenesis in upper aerodigestive tract. Int J Cancer. 2000;88(3):342-50. [PubMed: 11054661].

39. Homann N, Karkkainen P, Koivisto T, Nosova T, Jokelainen K, Salaspuro M. Effects of acetaldehyde on cell regeneration and differentiation of the upper gastrointestinal tract mucosa.J Natl Cancer Inst. 1997;89(22):1692-7. doi: 10.1093/jnci/89.22.1692. [PubMed: 9390538].

40. Coussens LM, Werb Z. Inflammation and cancer. Nature. 2002;420(6917):860-7. doi: 10.1038/nature01322. [PubMed:12490959]. [PubMed Central: PMC2803035].

41. Pujol FH, Devesa M. Genotypic variability of hepatitis viruses associated with chronic infection and the development of hepatocellular carcinoma. J Clin Gastroenterol. 2005;39(7):611-8. doi: 10.1097/01.mcg.0000170770.49394.92. [PubMed:16000930].

42. Berry LJ. Nowotny A: Antitumor effects of endotoxins. Cellular biology of endotoxin. 3. Amsterdam, Netherlands: Elsevier; 1985. p. 389-448.

43. Patyar S, Joshi R, Byrav DS, Prakash A, Medhi B, Das BK. Bacteria in cancer therapy: A novel experimental strategy. J Biomed Sci. 2010;17(1):21. doi: 10.1186/1423-0127-17-21. [PubMed: 20331869]. [PubMed Central: PMC2854109].

44. Panteli JT, Forkus BA, Van Dessel N, Forbes NS. Genetically modified bacteria as a tool to detect microscopic solid tumor masses with triggered release of a recombinant biomarker. Integr Biol. 2015;7(4):42334. doi: 10.1039/c5ib00047e. [PubMed: 25737274]. [PubMed Central: PMC4390529].

45. Wei MQ, Mengesha A, Good D, Anne J. Bacterial targeted tumour therapy-dawn of a new era. Cancer Lett. 2008;259(1):16-27. doi: 10.1016/j.canlet.2007.10.034. [PubMed: 18063294].

46. Fehleisen F. Ueber die Züchtung der Erysipelkokken auf künstlichem Nährboden und ihre Übertragbarkeit auf den Menschen. Dtsch Med Wochenschr. 1882;8(31):553-4. German.

47. Coley WB. Late results of the treatment of inoperable sarcoma by the mixed toxins of erysipelas and Bacillus prodigiosus. Am J Med Sci. 1906;131(3):375-430.

48. Connell HC. The study and treatment of cancer by proteolytic enzymes: Preliminary report. Can Med Assoc J. 1935;33(4):364-70. [PubMed: 20320024]. [PubMed Central: PMC1561462].

49. Coley WB. The treatment of malignant tumors by repeated inoculations of erysipelas. With a report of ten original cases.1893. Clin Orthop Relat Res. 1991;(262):3-11. [PubMed: 1984929].

50. Felgner S, Kocijancic D, Frahm M, Curtiss R, Erhardt M, Weiss S. Optimizing Salmonella enterica serovar Typhimurium for bacteria-mediated tumor therapy. Gut Microbes. 2016;7(2):171-7. doi: 10.1080/19490976.2016.1155021. [PubMed: 26939530]. [PubMed Central: PMC4856459].

51. Alexandroff AB, Nicholson S, Patel PM, Jackson AM. Recent advances in bacillus Calmette-Guerin immunotherapy in bladder cancer. Immunotherapy. 2010;2(4):551-60. doi: 10.2217/imt.10.32. [PubMed: 20636008].

52. Danino T, Prindle A, Kwong GA, Skalak M, Li H, Allen K, et al. Programmable probiotics for detection of cancer in urine. Sci Transl Med. 2015;7(289):289ra84. doi: 10.1126/scitranslmed.aaa3519. [PubMed: 26019220]. [PubMed Central: PMC4511399].

53. Bernardes N, Chakrabarty AM, Fialho AM. Engineering of bacterial strains and their products for cancer therapy. Appl Microbiol Biotechnol. 2013;97(12):5189-99. doi: 10.1007/s00253-013-4926-6. [PubMed: 23644748]

54. Liu S, Xu X, Zeng X, Li L, Chen Q, Li J. Tumor-targeting bacterial therapy: A potential treatment for oral cancer (Review). Oncol Lett. 2014;8(6):2359-66. doi: 10.3892/ol.2014.2525. [PubMed: 25364397] [PubMed Central: PMC4214492].

55. Rao RC, Zacks DN. Cell and gene therapy. In: Casaroli-Marano RP Zarbin MA, editors. Cell-based therapy for retinal degenerative disease. 53. Switzerland: Dev Ophthalmol, Karger; 2014. p. 167-77. doi: $10.1159 / 000357376$.

56. Baban CK, Cronin M, O'Hanlon D, O'Sullivan GC, Tangney M. Bacteria as vectors for gene therapy of cancer. Bioeng Bugs. 2010;1(6):38594. doi: 10.4161/bbug.1.6.13146. [PubMed: 21468205]. [PubMed Central: PMC3056088].

57. Forbes NS. Engineering the perfect (bacterial) cancer therapy. Nat Rev Cancer.2010;10(11):785-94.doi:10.1038/nrc2934. [PubMed: 20944664] [PubMed Central: PMC3756932].

58. Jiang SN, Park SH, Lee HJ, Zheng JH, Kim HS, Bom HS, et al. Engineering of bacteria for the visualization of targeted delivery of a cytolytic anticancer agent. Mol Ther. 2013;21(11):1985-95. doi: 10.1038/mt.2013.183. [PubMed: 23922014]. [PubMed Central: PMC3831040].

59. Cheng L, Ke Y, Yu S, Jing J. Co-delivery of doxorubicin and recombinant plasmid pHSP70-Plk1-shRNA by bacterial magnetosomes for osteosarcoma therapy. Int $J$ Nanomedicine. 2016;11:5277-86. doi: 10.2147/IJN.S115364. [PubMed: 27822032]. [PubMed Central: PMC5087786].

60. Yuan X, Lin X, Manorek G, Kanatani I, Cheung LH, Rosenblum MG, et al. Recombinant CPE fused to tumor necrosis factor targets human ovarian cancer cells expressing the claudin-3 and claudin- 4 receptors. Mol Cancer Ther. 2009;8(7):1906-15. doi:10.1158/1535-7163.MCT-09-0106. [PubMed: 19567823].

61. Rao SR, Ravishankar GA. Plant cell cultures: Chemical factories of secondary metabolites. Biotechnol Adv. 2002;20(2):101-53. doi: 10.1016/s0734-9750(02)00007-1. [PubMed: 14538059].

62. Chou TC, Zhang XG, Balog A, Su DS, Meng D, Savin K, et al. Desoxyepothilone B: An efficacious microtubule-targeted antitumor agent with a promising in vivo profile relative to epothilone B. ProcNatl Acad Sci U S A. 1998;95(16):9642-7. doi: 10.1073/pnas.95.16.9642. [PubMed 9689134]. [PubMed Central: PMC21392].

63. Kaur S, Kaur S. Bacteriocins as potential anticancer agents. Front Pharmacol. 2015;6:272. doi: 10.3389/fphar.2015.00272. [PubMed: 26617524] [PubMed Central: PMC4639596].

64. Nokhandani N, Naghavi-Alhosseini M, Davoodi H. The role of tolllike receptors in breast cancer. Journal of Inflammatory Disease. 2019;23(3):262-77.

65. Ribi E, Takayama K, Milner K, Gray GR, Goren M, Parker R, et al. Regression of tumors by an endotoxin combined with trehalose mycolates of differing structure. Cancer Immunol Immunother.1976;1(4).doi: 10.1007/bfo0200103.

66. Davoodi H, Hashemi SR, Seow HF. 5-fluorouracil induce the expression of TLR4 on HCT116 colorectal cancer cell line expressing different variants of TLR4. Iran J Pharm Res. 2013;12(2):453-60. [PubMed: 24250621]. [PubMed Central: PMC3813241].

67. Walenkamp AM, Boer IG, Bestebroer J, Rozeveld D, Timmer-Bosscha $\mathrm{H}$, Hemrika W, et al. Staphylococcal superantigen-like $10 \mathrm{in}$ hibits CXCL12-induced human tumor cell migration. Neoplasia. 2009;11(4):333-44. doi: 10.1593/neo.81508. [PubMed: 19308288]. [PubMed Central: PMC2657885].

68. Shear MJ, Andervont HB. Chemical treatment of tumors. III. Separation of hemorrhage-producing fraction of B. coli filtrate. Exp Biol Med. 1936;34(3):323-5. doi: 10.3181/00379727-34-8605p.

69. Xiong L, Teng JL, Botelho MG, Lo RC, Lau SK, Woo PC. Arginine metabolism in bacterial pathogenesis and cancer therapy. Int J Mol Sci. 2016;17(3):363. doi: 10.3390/ijms17030363. [PubMed: 26978353]. 
[PubMed Central: PMC4813224].

70. Feun L, You M, Wu CJ, Kuo MT, Wangpaichitr M, Spector S, et al. Arginine deprivation as a targeted therapy for cancer. Curr Pharm Des. 2008;14(11):1049-57. doi: 10.2174/138161208784246199. [PubMed: 18473854]. [PubMed Central: PMC3096551].

71. Wheatley DN, Campbell E. Arginine catabolism, liver extracts and cancer. Pathol Oncol Res. 2002;8(1):18-25. doi: 10.1007/BF03033696. [PubMed: 11994758].

72. Patil MD, Bhaumik J, Babykutty S, Banerjee UC, Fukumura D. Arginine dependence of tumor cells: Targeting a chink in cancer's armor. Oncogene. 2016;35(38):4957-72. doi: 10.1038/onc.2016.37. [PubMed: 27109103]. [PubMed Central: PMC5457742].

73. Kuo MT, Savaraj N, Feun LG. Targeted cellular metabolism for cancer chemotherapy with recombinant arginine-degrading enzymes. Oncotarget. 2010;1(4):246-51. doi: 10.18632/oncotarget.135. [PubMed: 21152246]. [PubMed Central: PMC2998341].

74. Ni Y, Li Z, Sun Z, Zheng P, Liu Y, Zhu L, et al. Expression of arginine deiminase from Pseudomonas plecoglossicida CGMCC2039 in Escherichia coli and its anti-tumor activity. Curr Microbiol. 2009;58(6):593-8. doi: 10.1007/s00284-009-9376-0. [PubMed 19280262].

75. Lind DS. Arginine and cancer. J Nutr. 2004;134(10 Suppl):2837S-41S. discussion 2853S. doi: 10.1093/jn/134.10.2837S. [PubMed: 15465796].

76. Frankel RB, Bazylinski DA. How magnetotactic bacteria make magnetosomes queue up. Trends Microbiol. 2006;14(8):329-31. doi 10.1016/j.tim.2006.06.004. [PubMed:16782341].

77. Sun JB, Duan JH, Dai SL, Ren J, Guo L, Jiang W, et al. Preparation and anti-tumor efficiency evaluation of doxorubicin-loaded bacterial magnetosomes: magnetic nanoparticles as drug carriers isolated from Magnetospirillum gryphiswaldense. Biotechnol Bioeng. 2008;101(6):1313-20. doi: 10.1002/bit.22011. [PubMed: 18980188].

78. Xiang Z, Yang X, Xu J, Lai W, Wang Z, Hu Z, et al. Tumor detection using magnetosome nanoparticles functionalized with a newly screened EGFR/HER2 targeting peptide. Biomaterials. 2017;115:53-64 doi: 10.1016/j.biomaterials.2016.11.022. [PubMed: 27888699].

79. Alphandery E, Chebbi I, Guyot F, Durand-Dubief M. Use of bacterial magnetosomes in the magnetic hyperthermia treatment of tumours: A review. Int J Hyperthermia. 2013;29(8):801-9. doi 10.3109/02656736.2013.821527. [PubMed: 24024595].

80. Agrawal N, Bettegowda C, Cheong I, Geschwind JF, Drake CG, Hipkiss EL, et al. Bacteriolytic therapy can generate a potent immune response against experimental tumors. Proc Natl Acad Sci U S A. 2004;101(42):15172-7. doi: 10.1073/pnas.0406242101. [PubMed
15471990]. [PubMed Central: PMC523456].

81. Dang LH, Bettegowda C, Huso DL, Kinzler KW, Vogelstein B. Combination bacteriolytic therapy for the treatment of experimental tumors. Proc Natl Acad Sci U S A. 2001;98(26):15155-60. doi: 10.1073/pnas.251543698. [PubMed: 11724950]. [PubMed Central: PMC64999].

82. Phan TX, Nguyen VH, Duong MT, Hong Y, Choy HE, Min JJ. Activation of inflammasome by attenuated Salmonella typhimurium in bacteriamediated cancer therapy. Microbiol Immunol. 2015;59(11):664-75. doi: 10.1111/1348-0421.12333. [PubMed: 26500022].

83. Stern C, Kasnitz N, Kocijancic D, Trittel S, Riese P, Guzman CA, et al. Induction of $\mathrm{CD} 4(+)$ and $\mathrm{CD} 8(+)$ anti-tumor effector $\mathrm{T}$ cell responses by bacteria mediated tumor therapy. Int J Cancer. 2015;137(8):2019-28. doi: 10.1002/ijc.29567. [PubMed: 25868911].

84. Sivan A, Corrales L, Hubert N, Williams JB, Aquino-Michaels K, Earley ZM, et al. Commensal Bifidobacterium promotes antitumor immunity and facilitates anti-PD-L1 efficacy. Science. 2015;350(6264):1084-9. doi: 10.1126/science.aac4255. [PubMed: 26541606]. [PubMed Central: PMC4873287].

85. Galon J, Angell HK, Bedognetti D, Marincola FM. The continuum of cancer immunosurveillance: prognostic, predictive, and mechanistic signatures. Immunity. 2013;39(1):11-26. doi: 10.1016/j.immuni.2013.07.008. [PubMed: 23890060].

86. Thomas L, Lawrence HS. Cellular and humoral aspects of the hypersensitive states. New York: Hoeber-Harper. 1959:529-32.

87. Moore RJ, Owens DM, Stamp G, Arnott C, Burke F, East N, et al. Mice deficient in tumor necrosis factor-alpha are resistant to skin carcinogenesis. Nat Med. 1999;5(7):828-31. doi: 10.1038/10552. [PubMed: 10395330].

88. Murphy C, Rettedal E, Lehouritis P, Devoy C, Tangney M. Intratumoural production of TNF $\alpha$ by bacteria mediates cancer therapy. PLoS One. 2017;12(6). e0180034. doi: 10.1371/journal.pone.0180034. [PubMed: 28662099]. [PubMed Central: PMC5491124].

89. Abel AM, Yang C, Thakar MS, Malarkannan S. Natural killer cells: Development, maturation, and clinical utilization. Front Immunol. 2018;9:1869. doi: 10.3389/fimmu.2018.01869. [PubMed: 30150991]. [PubMed Central: PMC6099181].

90. Rao VP, Poutahidis T, Ge Z, Nambiar PR, Boussahmain C, Wang YY, et al. Innate immune inflammatory response against enteric bacteria Helicobacter hepaticus induces mammary adenocarcinoma in mice. Cancer Res. 2006;66(15):7395-400. doi: 10.1158/0008-5472.CAN06-0558. [PubMed:16885333]. 